Trinity University

Digital Commons@ Trinity

Economics Faculty Research

Economics Department

$4-2012$

\title{
Economies in Transition and in Development: A Possible Warning from Adam Smith
}

Maria Pia Paganelli

Trinity University, mpaganel@trinity.edu

Follow this and additional works at: https://digitalcommons.trinity.edu/econ_faculty

Part of the Economics Commons

\section{Repository Citation}

Paganelli, M.P. (2012). Economies in transition and in development: A possible warning from Adam Smith. The European Journal of the History of Economic Thought, 19(2), 149-163. doi: 10.1080/09672567.2010.499470

This Article is brought to you for free and open access by the Economics Department at Digital Commons @ Trinity. It has been accepted for inclusion in Economics Faculty Research by an authorized administrator of Digital Commons @ Trinity. For more information, please contact jcostanz@trinity.edu. 


\section{Economies in transition and in development: A possible warning from Adam Smith}

\section{Maria Pia Paganelli}

\section{Introduction}

Adam Smith was concerned with the nature and causes of economic growth and development. One may therefore ask if it is possible to use his work, even if only as speculation, in order to gather useful insights about today's developing or transitional economies. With all the due caveats, this paper asks: if Adam Smith were alive today, what would he say about transitioning and developing economies? Testing whether Adam Smith would be correct in his analysis, I leave to other work.

Asking Adam Smith, even if only hypothetically, about transitioning and developing economies adds to the existing literature, which focuses mostly on market-building and/or institution-building. ${ }^{1}$ Formal incentives and calculations, deriving from markets or institutions, are necessary but not sufficient to understand the problems of transition and development (and to suggest solutions). Knack and Keefer (1997) and Paul Seabright (2004), among others, recognise it and add social trust to the picture; James Coleman (1988), Robert Putnam (2006) and Amos Witztum (1994, 2008), among others, add social capital and social attitudes. Adam Smith (1759, 1776) would add vanity and our desire to gain approbation.

Smith's analysis is based on the belief that we have a variety of motivations. Among other things, we are moved by an innate desire to be

\section{Address for correspondence}

Maria Pia Paganelli, Department of Economics, Trinity University, One Trinity Place, San Antonio, TX 78212, USA; e-mail: maria_paganelli@yahoo.com

1 On the relevance of Adam Smith and the Scottish Enlightenment for the new comparative economics see, for example, Djankov et al. 2003. On the importance of institutions and their adaptability to different contexts, see Zweynert and Goldschmidt (2006), North et al. (2008). See also Arrighi (2007).

The European Journal of the History of Economic Thought ISSN 0967-2567 print/ISSN 1469-5936 online (c) 2012 Taylor \& Francis

http://www.tandf.co.uk/journals

http://dx.doi.org/10.1080/09672567.2010.499470 
praised by others. The desire to better one's condition, which follows us from the cradle to the tomb, is in fact an expression of our desire to gain approbation. The more riches we have, the more we are able to show off; and the more we show off, the more approbation we receive. ${ }^{2}$

It is because mankind is disposed to sympathize more entirely with our joy than with our sorrow, that we make parade of our riches, and conceal our poverty ... [I]t is chiefly from this regard to the sentiments of mankind, that we pursue riches and avoid poverty ... From whence, then, arises ... that great purpose of human life which we call bettering our condition? To be observed, to be attended to, to be taken notice of with sympathy, complacency, and approbation, are all the advantages which we can propose to derive from it. It is the vanity, not the ease or the pleasure, which interest us. ... Vanity is always grounded upon the belief of our being the object of attention and approbation. The rich man glories in his riches, because he feels that they naturally draw upon him the attention of the world.... The poor man, on the contrary, is ashamed of his poverty. He feels that it either places him out of the sight of mankind, that if they take any notice of him, they have, however, scarce any fellowfeeling with the misery and distress which he suffers. (TMS I.iii.2.1: 50-1)

In Smith's framework, therefore, man does not live by bread alone: ${ }^{3}$ we may have the most beautiful rule and/or institution, but if there is an opportunity to improve our image in the eyes of others, we are willing to break the rule and ignore the institution.

In the next section, I will show in detail how, for Smith, the prospect of acquiring large amounts of wealth, because of the large gains in approbation that follow, may give us strong enough incentives to disregard moral and formal rules. This may become a problem when there are large amounts of wealth that can be gained. In his time, Smith saw the sudden abundance of wealth associated with the opening of the New World's markets and the monopoly privileges granted to deal in them. Likewise, today he would see the sudden abundance of wealth commonly associated with the opening of Western markets or with the giving of foreign aid to some transitioning and developing countries. In the following section, I will present how Smith identifies rent-seeking, public bankruptcy and factions as pernicious consequences of our vain desire to be approved, combined with this sudden abundance of wealth. Likewise, today he would identify similar kinds of problems afflicting some transitioning and developing economies. The final section elaborates on a possible way Smith would propose to develop a free and prosperous society - gradual introduction of commerce. A slow exposure to great riches may generate smaller profit

2 Smith also tells us that we sympathise with sorrows and poverty as well as with joy and wealth. Thanks to a referee for pointing this out.

3 Cf. Hirschman (1997), who collapses vector rewards into scalar in Adam Smith's work. 
opportunities, which, in turn, would generate both weaker rent-seeking opportunities and better odds of developing a sense of trust and cooperation that is strong enough to resist the temptation of grabbing new available wealth. Concluding remarks end the paper.

\section{A Smithian framework for analysing some problems in some transitioning and developing economies}

Smith believes that we are motivated by an innate desire to gain the approbation of others. Our vain desire to gain approbation motivates us to work hard and produce more and better goods. This desire is the driving force of economic betterment. It is a benign force that supports the working of the invisible hand, the benefits of which we are so familiar with ${ }^{4}$.

But this same desire may not always be benign. Smith explains that there are two ways in which we gain approbation: virtue and wealth.

Two different roads are presented to us, equally leading to the attainment of this so much desired object [the respect and admiration of mankind]; the one, by the study of wisdom and the practice of virtue; the other, by the acquisition of wealth and greatness. Two different characters are presented to our emulation; the one, of proud ambition and ostentatious avidity; the other, of humble modesty and equitable justice. Two different models, two different pictures, are held out to us, according to which we may fashion our own character and behaviour; the one more gaudy and glittering in its colouring; the other more correct and more exquisitely beautiful in its outline: the one forcing itself upon the notice of every wandering eye; the other, attracting the attention of scarce any body but the most studious and careful observer. (TMS I.iii.3.2: 62)

The difference between virtue and wealth is that wealth is more visible and more easily recognizable than virtue. Indeed:

[our] fascination of greatness ... is so powerful, that the rich and the great are too often preferred to the wise and the virtuous. ... The undistinguishing eye of the great mob of mankind can well enough perceive the [plain and palpable difference of birth and fortune]: it is with difficulty that the nice discernment of the wise and the virtuous can sometimes distinguish the [the invisible and often uncertain difference of wisdom and virtue]. (TMS VI.ii.1.20: 226)

Smith's logic is the following. ${ }^{5}$ The approbation we receive depends on a combination of our wealth and our virtue. An increase in wealth or an increase

4 On the diffusion of the idea that the individual's drive to better his condition generates positive social consequences see, among the large literature, Samuels (2007).

5 For a formal model of the Smithian logic applied to the labour market, see Levy (1999). 
in virtue increases approbation. Similarly, a decrease in wealth or a decrease in virtue decreases approbation. A vicious act may not affect the extent to which one is viewed with approval if the decrease in approbation due to immoral conduct is compensated by an increase in approbation due to wealth. The opposite is also true. But an increase or decrease in wealth is more recognisable than an increase or decrease in virtue. So, large enough increases in wealth more than compensate for immoral behaviours. Indeed, the approbation offered to the rich, simply because of their wealth, is usually large enough to overshadow many otherwise unapproved actions. The amount of admiration offered to the rich may therefore induce individuals to engage in the despicable breaking of formal and moral rules that allows them to parade large amounts of material possessions. Smith indeed tells us that:

The candidates for fortune too frequently abandon the paths of virtues ... They often endeavour, therefore, not only by fraud and falsehood, the ordinary and vulgar arts of intrigue and cabal; but sometimes by the perpetration of the most enormous crimes, by murder and by assassination, by rebellion and civil war, to supplant and destroy those who oppose or stand in the way of their greatness. (TMS I.iii.3.8: 64-5)

The gain from grossly immoral actions may be enormous admiration. So people pursue wealth, when there is wealth to pursue, even at the cost of disregarding moral and institutional rules, because it is easier to gain the desired approbation by showing off material possessions than by behaving virtuously. Indeed, by parading their wealth, the rich gain approbation while their misbehaviours are ignored (TMS I.iii.3.2: 62).

Smith further develops the idea that we use a double standard for the rich and for the poor. The same action, which is 'regarded with the utmost abhorrence and detestation' when coming from poor 'common people', is 'generally treated with a good deal of indulgence, and ... easily either excused or pardoned altogether' when coming from the rich. We have indeed 'two different schemes or systems of morality current at the same time; of which one may be called the strict or austere; the other the liberal, or, if you will, the loose system'. The 'loose' moral system is used to judge the rich, the 'austere' system to judge the poor (WN V.i.g.10: 794).

Smith also notices that the temptations to engage in reproachable behaviours increase with society's increase in sudden opportunities for wealth accumulation, such as the ones that come with the opening of rich international markets. Now there are plenty of things to buy and show off (WN I.i.c.7: 181). We can distinguish ourselves from others by having curious trinkets (TMS IV.i.8: 182) or 'foreign wares, [which are preferred] to cheaper and better goods of the same kind that were made at home [merely because they are foreign]' (WN IV.ii.41: 469). Today, we would think in terms of electronic gadgets, sports cars, jewellery and designer 
garments, but the logic is the same: trinkets and baubles give us glamour. Their consumption has no limits because "where [a person] can spend the greatest revenue upon his own person, he frequently has no bound to his expense, because he frequently has no bounds to his vanity, or to his affection for his own person' (WN III.iv.16: 422). The opening of rich international markets offers both trinkets and opportunities to get them.

\section{Some possible problems}

Smith adds to the existing literature the warning that the prospect of suddenly acquiring large amounts of wealth, because of the large gains in approbation that follow, gives us strong enough incentives to disregard moral and formal rules. The large amounts of wealth available with the sudden enlargement of international trade, for example, generate strong incentives to seek monopolistic rents, in a sense regardless of the existing political regime. I think Smith would agree with Djankov et al. (2003) when they suggest that looking at transition and development in terms of 'the best political system for economic reform' (p. 597) may not be enough. ${ }^{6}$ The problems that Smith identifies, as we will see below, namely, rentseeking, public debt and factions, seem to afflict all political regimes. Indeed, the opening of some transitioning and developing economies to the rich and industrialised West today has enough in common with the opening of colonial markets in the eighteenth century to make Smith's fear of the potential risks associated with the sudden presence of large amounts of wealth relevant. Today, we often hear about Eastern European corruption, where big industrial tycoons collude with politicians to fatten their wallets while exploiting their struggling fellow-citizens and hindering growth. We often hear about African politicians pocketing international aid intended for starving sick children or for the construction of schools, and fomenting civil wars to maintain their power to collect aid, de facto sabotaging economic development. We often hear about some unscrupulous businessman who is willing to risk the life of many children to get a few extra pennies by selling abroad toys made with poisonous materials.

\subsection{The rent-seeking problem}

Where large profit opportunities are presented, they can become exorbitant if a government grants monopoly privileges, and vain merchants

6 For some empirical studies on the relation between political forms and development, see among others Heybey and Murrell (1999); Hausmann et al. (2005); Rodrik (2008). 
and manufacturers can become voraciously ambitious and derail economic growth (WN IV.viii.c.43: 604). Indeed, because of the incentives offered by sudden vast wealth, merchants and manufacturers are driven by their 'mean rapacity, monopolizing spirit, [and] interested sophistry ... [which] confounded the common sense of mankind. Their interest is, in this respect, directly opposite to that of the great body of the people' (WN IV.iii.c.9-10: 493-4). Under these circumstances, they are 'an order of men whose interest is never exactly the same with the public, who generally have an interest to deceive and even oppress the public, and who accordingly have, upon many occasions, both deceived and oppressed it' (WN I.xi: 10, 267). Smith spends most of book IV explaining the damages of rent-seeking (see in particular, but not only, WN IV.i.10: 434, IV.ii.38: 467, IV.iii.c.10: 493), as Jerry Evensky (2005) has highlighted. ${ }^{7}$

As mentioned previously, this is not the place to question whether Smith is correct or not, whether in his day or today. Herein, I would just like to provide a possible way to view how Smith presents his argument. According to Smith, merchants and manufacturers are willing to ignore the existing rules and institutions because, thanks to monopoly powers, they will gain a lot of wealth and therefore improve their position in the eyes of others. So, with morally questionable means, they either flatter or 'intimidate the legislature' to gain monopoly privileges. The consequent mercantilist laws can be so unjust that:

the cruellest of our revenue laws, I will venture to affirm, are mild and gentle, in comparison of some of those which the clamour of our merchants and manufacturers has extorted from the legislature, for the support of their own absurd and oppressive monopolies. Like the laws of Draco, these laws may be said to be all written in blood. (WN IV.viii.17: 648)

In fact, Smith tells us, great merchants and manufacturers are willing and able to 'extort' tragic international wars from the legislature, '[f]or the sake of that little enhancement of price which this monopoly might afford our producers' (WN IV.viii.53: 661). Their great material gain makes us forgive and forget the objectionable methods used to win them.

Additionally, not only do rent-seekers destroy the benefits and progress of trade, they fool the common people into supporting the rent-seekers:

That it was the spirit of monopoly which originally invented and propagated this doctrine [of government-granted economic privileges], cannot be doubted; and they who first taught it were by no means such fools as they who believed it.

7 For a recent example of looking at Smith to see the political agenda driving his analysis, see Hueckel (2009). 
In every country it always is and must be the interest of the great body of the people to buy whatever they want of those who sell it cheapest. The proposition is so very manifest, that it seems ridiculous to take any pains to prove it; nor could it have been called in question, had not the interested sophistry of merchants and manufacturers confounded the common sense of mankind (WN IV.iii.c.10: 493-4)

Smith's conclusion is that rent-seekers permanently mutilate commerce. Once privileges are granted, they will not be taken away. ${ }^{8}$ Smith is convinced that:

[t]o expect, indeed, that the freedom of trade should ever be entirely restored in Great Britain, is as absurd as to expect that an Oceana or Utopia should ever be established in it. Not only the prejudices of the publick, but what is much more unconquerable, the private interests of many individuals, irresistibly oppose it. (WN IV.ii.43: 471)

The damage that great merchants and manufacturers inflict upon society endures time and change.

In developed commercial societies, the damages of rent-seeking are counterbalanced by the strength of the market. Smith tells us indeed that:

We must carefully distinguish between the effects of the colony trade and those of the monopoly of that trade. The former are always and necessarily beneficial; the latter always and necessarily hurtful. But the former are so beneficial, that the colony trade, though subject to a monopoly, and notwithstanding the hurtful effects of that monopoly, is still upon the whole beneficial, and greatly beneficial; though a good deal less so than it would otherwise be. (WN IV.vii.c.47: $607-8)$

Or again: 'If the colony trade, however, even as it is carried out at present is advantageous to Great Britain, it is not by the means of monopoly, but in spite of the monopoly' (WN IV.vii.c.50: 609). But in transitioning and developing economies, commerce may not be strong and mature enough to provide large enough benefits to compensate for the downsides of rentseeking. Today's public choice analysis of transitioning and developing countries tells a very similar story. The large gains from privileges in trade with the rich West and generous foreign aid packages offer incredible rentseeking opportunities in some transitioning and developing countries, which may permanently damage their economies. Rent-seeking indeed seems to be one of the most aggressive and dangerous obstacles and threats to growth in developing and transitioning economies, as Anne Krueger

8 For a formal treatment see Tullock (1975). 
(1974), Charles Rowley (2000) and David Hoffman (2002), among others, have shown.

\subsection{The public debt problem}

Smith identifies a second menace applicable to transitioning and developing economies: 'sovereigns' face the same vain temptations brought about by the new available riches (WN V.iii.2-3: 908). The sovereign will spend his revenue on frivolous trinkets during times of peace and will have to incur debt to cover regular and unexpected expenditure. But unfortunately, '[t] he progress of the enormous debts which at present oppress, and will in the long run probably ruin, all the great nations of Europe, has been pretty uniform' (WN V.iii.10: 911). Despite the differences, one cannot avoid thinking of the Philippines, Indonesia, Argentina, Romania and the many other countries in which the 'sovereigns' and their families enriched themselves with public funds and foreign aids, leaving their countries bankrupt and dealing with the horrors of hyperinflation, even in the absence of the need to increase expenditure to defend themselves from external threats. The vanity of the politicians, then and now, creates incentives to bypass moral and legal constraints, dangerously compromising growth.

\subsection{Factions}

Finally, even if factions are not directly related to the introduction of large amounts of wealth, they are a further common point between Smith and today's developing and transitioning countries. Smith looks at factions as loci where one can gain approbation by disregarding existing rules and institutions, with potentially destabilising effects for society and growth. Smith indeed condemns factions as 'the [greatest] corrupters of moral sentiments' (TMS III.3.43: 156).

People join factions in civil and religious wars for the sake of vain glory and immediate approbation (TMS III.3.42: 154-5). A group can become a self-referential source of a moral code, or binding social capital as we would say today, at the potential expense of social peace and harmony and at the risk of many deaths (TMS III.3.43: 155), including the death of functioning institutions. For the individual, the benefits of receiving the approbation of the members of one's faction are much larger than the cost of using dreadful methods to promote one's faction's victory. Unfortunately, today's events seem to confirm Smith's analysis and corroborate the detrimental effects that factions may have on economic growth, especially when a strong ethnic component is added, in countries where the economy is not stable enough to sustain continuous growth. 


\section{A Smithian framework for analysing possible solutions for transitioning and developing economies}

Smith's diagnosis of some of the evils in his time can be used to diagnose some of the evils that some transitioning and developing economies face in our time. His prognosis may be applied to us today as well. He claims:

Commerce and manufactures can seldom flourish in any state which does not enjoy a regular administration of justice, in which the people do not feel themselves secure in the possession of their property, in which the faith of contracts is not supported by law, and in which the authority of the state is not supposed to be regularly employed in enforcing the payment of debts from all those who are able to pay. Commerce and manufactures, in short, can seldom flourish in any state in which there is not a certain degree of confidence in the justice of government. (WN V.iii.7: 910)

In addition to the attention given to market formation and institution building, Smith would encourage transitioning and developing economies to pay great attention to situations in which our vanity may induce us to trump good formal or moral rules and institutions. The snatching of large amounts of wealth that is up for grabs would most likely be his first priority. In fact, Smith offers one explicit policy prescription: avoid rent-seeking, if you can.

The legislature, were it possible that its deliberations could be always directed, not by the clamourous importunity of partial interests, but by an extensive view of the general good, ought upon this very account, perhaps, to be particularly careful neither to establish any new monopolies of this kind, nor to extend further those which are already established. Every such regulation introduces some degree of real disorder into the constitution of the state, which it will be difficult afterwards to cure without occasioning another disorder. (WN IV.ii.44: 471-2)

Smith's advice sounds like some contemporary advice. Acemoglu (2008) claims, in fact, that:

Every policy intervention creates winners and losers. The winners not only gain economically, but also become politically powerful. These politically powerful groups can then become a barrier against further progress. This is well illustrated by the experience of import substitution, which supported nascent industrial groups in many developing economies. In most cases, the subsidized conglomerates were highly inefficient and became a formidable obstacle to further reform.

His advice: 'Refrain from policies that will create new and potentially dangerous political constituencies' (p. 5).

But how can it be possible to refrain? How can it be possible for the legislature to not be directed by 'the clamourous importunity of partial 
interests'? Smith appeals to the legislator, claiming that he should not fall for the flattery of the self-interested merchants but should preserve the natural system of liberty out of reverence toward its beauty. ${ }^{9}$ But our civic spirit is generally weak (TMS IV.1.11). So how can it be strengthened? Additionally, if a 'regular administration of justice' is needed for commerce to flourish, how do we get this 'justice of government', which is so deeply missing in most transitioning and developing countries?

One can infer at least two suggestions from Smith's work. One is to avoid situations that may generate rent-seeking opportunities, as we just saw. The other is to develop a strong sense of moral respect for rules, for institutions and for the public good. Both of these prescriptions collapse into only one: the gradual introduction of commerce. A gradual opening of the large wealth offered by international trade restrains rent-seeking opportunities and is likely to develop sound institutions and a strong moral sense that leads to respect for them. Smith indeed tells us that a just set of institutions and a public spirit do not come from any human wisdom, plan or design. They are not something that can be imposed from above or from the outside. They are something that comes, gradually, with commerce. Only commerce, when very gradually introduced, can ignite what no army or wisdom is able to start (WN III.iv.10: 418, WN V.i.g. 24-25: 803).

Smith claims indeed that it is from the gradual introduction of commerce that we generate both a strong set of institutions and the conditions that develop a strong moral sense, which would be fertile ground for prosperity. He credits David Hume for being the first to realise that 'commerce and manufactures gradually introduced order and good government, and with them, the liberty and security of individuals... This, though it has been the least observed, is by far the most important of all their effects' (WN III.iv.4: 412; see also Rosenberg 1968, 1990; Rasmussen 2006).

It is, therefore, the gradual introduction of commerce and manufactures that unintentionally generates the regular administration of justice - the foundation of commercial prosperity - and the internalisation of its rules may help develop the strong moral sense needed to countervail the strong temptations of monopolies. 'The gradual improvements of arts, manufacturers, and commerce' not only is the foundation of good institutions but also of the much-needed sense of respect for them.

The Smithian idea of the gradual introduction of commerce being so beneficial for stable development - and his criticism of the sudden introduction of large amounts of wealth that can be grabbed by rapacious big merchants and manufacturers - enhance the idea of gradualism already present in the transition and development literature, as in Mancur Olson

9 For a recent treatment, see Evensky, (2005) and Hanley and Paganelli (2009). 
(1963) and Peter Murrell (1992). Smith would add to it the role of approbation and the size of the stakes available. The gradual introduction of small amounts of wealth would reduce the incentives for immoral and shameful grabbing and for disrespecting rules, as the gain in approbation from material wealth may not be as large as the loss of approbation due to breaking the rules of appropriate conduct. Even Smith's example of 'fast' economic growth - America - implies pretty small incremental profit opportunities. America has grown so much and so 'fast' because its growth is based on agriculture and abundance of land, and cultivating abundant land, in Smith's time, was not going to change one's fortune overnight. On the other hand, large wealth available thanks to monopoly privileges would increase the incentive to disregard rules and institutions to grab the riches and increase the opportunity to be looked up at by others. Vanity combined with large amounts of sudden wealth increase the incentive to ignore institutional and moral rules and to commit despicable and economically deleterious acts.

With this, by no means am I suggesting that Smith would encourage isolationism. To the contrary, the exposure to international trade is fundamental in Smith's logic. I am simply saying that he may suggest a gradual exposure to small profit opportunities rather than abstaining or jumping at once at huge amounts of wealth. The slow introduction of small profits would facilitate the gradual introduction of commerce so commonly linked with the increased chances to generate successful institutions and help develop the moral sense that is required to support them.

That Smith favours gradualism can be inferred not only from the abovementioned description of the emergence of the most successful economies of his time but also from some of his policy prescriptions for them. Too-sudden political changes are dangerous because they do not allow enough time for adjustment. So when talking about the possibility of liberalising international trade, he vocally calls for gradualism: 'To open the colony trade all at once to all nations, might not only occasion some transitory inconveniency, but a great permanent loss to the greater part of those whose industry or capital is at present engaged in it' (WN IV.vii.c.44: 606). Commerce, and international commerce in particular, should be pursued, always. But gradually. So he prescribes that:

a moderate and gradual relaxation of the laws ... seems to be the only expedient... which, by gradually diminishing one branch of her industry and gradually increasing all the rest, can by degrees restore all the different branches of it to that natural, healthful, and proper proportion which perfect liberty necessarily establishes, and which perfect liberty can alone preserve. (WN IV.vii.c.44: 606; see also WN IV.ii.40: 469) 
As for public debt, Smith tells us that the gradual introduction of commerce may also provide remedies against its abuses, more effectively than when sudden changes of wealth are present. ${ }^{10}$ Smith claims that if a stable and developed commercial state "commonly brings along with it the necessity of borrowing, it likewise brings along with it the facility of doing so’ (WN V.iii.5: 910).

The problem of factions is the least related to commerce. Yet Smith draws ideas for possible solutions from markets. If factions, such as religious sects, are multiplied so much as to render each one of them too weak to affect national policies, then factions may cease to be a threat to development and may actually help the moral formation of individuals. Smith claims indeed that factions can be 'the most splendid opportunities for the display of public spirit' (TMS VI.ii.2.13: 232) and 'the best schools of selfcommand' (VI.iii.12: 241, as well as TMS VI.iii.19-20: 245-246; see also TMS VI.ii.2.13-14: 232).

The counterweight against the growth-detrimental threats that Smith describes seems therefore to be a combination of a strong moral sense and the gradual development of commerce itself (WN IV.vii.c.47-54: 607-10). The two seem to develop symbiotically. A moral path may be more easily followed in a society where the growth of commerce is gradual, possibly because the number of questionable shortcuts available is not high. The slow yet steady introduction of commerce, with its small yet steady profit opportunities, may facilitate the habit of justice. The person who enriches himself through honest hard work rather than by dishonest shortcuts indeed gains:

that eminent esteem with which all men naturally regard a steady perseverance in the practice of frugality, industry, and application, though directed to no other purpose than the acquisition of fortune.... We not only approve, therefore, but in some measure admire his conduct, and think it worthy of a considerable degree of applause. It is the consciousness of this merited approbation and esteem which alone is capable of supporting the agent in this tenour of conduct (TMS IV.2.8:189-90)

Also, the economy grows in a healthy fashion (TMS, IV.1.9-10: 183-4).

\section{Conclusions}

Some transitioning and developing economies have much in common with the economies described by Adam Smith, where large profit opportunities

10 For a recent analysis of Smith's position on public debt, see Paganelli (2006). 
are suddenly introduced. Smith adds to the transition and development analysis our natural vanity and payoffs measured in approbation. The desire for approbation makes individuals and society better off under most circumstances. But it can also destroy opportunities for growth. If there are enough incentives to rely only on wealth to receive approbation, then good institutions, the rule of law and moral conduct may be ignored, generating some of the malfunctions we observe today in some non-developed countries. Smith can explain eighteenth-century mercantilist policies and could explain twentieth-century rent-seeking and corruption in some transitioning and developing countries as a consequence of our vain attempts to show off in front of others. Hope, from Smith, may be inferred through his analysis of the gradual introduction of commerce, its consequential fair administration of justice and the development of morality and civic spirit that may be able to constrain those rent-seekers who are so detrimental to growth.

Smith may not be able to explain all failures or successes in developing and transitioning countries, but he can still offer us an effective framework that enhances our existing means of analysis.

\section{References}

Acemoglu, Daron (2008). Interaction between governance and growth. In D. North, D. Acemonglu, F. Fukuyama and D. Rodrik (Eds.), Governance, Growth, and Development Decision-making. Washington DC: The World Bank: pp. 1-9.

Arrighi, Giovanni (2007). Adam Smith Goes to China: Lineages of the Twenty-First Century. London, New York: Verso.

Coleman, James S. (1988). Social capital in the creation of human capital. American Journal of Sociology, 94, Supplement: S95-120.

Djankov, Simeon, Glaeser, Edward, La Porta, Rafael, Lopez-de-Silandes, Florencio and Shleifer, Andrei (2003). The new comparative economics. Journal of Comparative Economics, 27: 595-619.

Evensky, Jerry (2005). Adam Smith's Moral Philosophy. Cambridge: Cambridge University Press.

Hanley, Ryan, and Paganelli, Maria Pia (2009). Adam Smith on money, mercantilism and the system of natural liberty. In D. Carey (Ed.), Money and the Enlightenment. Oxford: Voltaire Foundation. Forthcoming.

Hausmann, Ricardo, Pritchett, Lant and Rodrik, Doni (2005). Growth accelerations. Journal of Economic Growth, 10: 303-29.

Heybey, Berta and Murrell, Peter (1999). The relationship between economic growth and the speed of liberalization during transition. Policy Reform, 3: 121-37.

Hirschman, Albert O. (1997). The Passions and the Interests: Political Arguments for Capitalism before Its Triumph. Princeton: Princeton University Press.

Hoffman, David (2002). The Oligarchs: Wealth and Power in the New Russia. New York: Public Affairs. 


\section{Maria Pia Paganelli}

Hueckel, Glenn (2009). 'In the Heat of Writing': Polemics and the 'Error of Smith' in the matter of the corn bounty. In J. Young (Ed.), The Elgar Companion to Adam Smith. Cheltenham, UK: Edward Elgar. Forthcoming.

Knack, Stephen and Keefer, Philip (1997). Does social capital have an economic payoff? A cross-country investigation. The Quarterly Journal of Economics, 12 (4): 1251-88.

Krueger, Anne O. (1974). The political economy of the rent-seeking society. American Economic Review, 64: 291-303.

Levy, David M. (1999). Adam Smith's Katallatic model of gambling: Approbation from the Spectator. Journal of the History of Economic Thought, 21: 81-91.

Murrell, Peter (1992). Conservative political philosophy and the strategy of economic transition. East European Politics and Societies, 6 (1): 3-16.

Olson, Mancur (1963). Rapid growth as a destabilizing force. The Journal of Economic History, 23 (4): 529-52.

Paganelli, Maria Pia (2006). Vanity and the Daedalian wings of paper money in Adam Smith. In E. Schlieser and L. Montes (Eds.), New Voices on Adam Smith. London/ New York: Routledge: pp. 271-89.

Paganelli, Maria Pia (2009). 'Approbation and the desire to better one's condition in Adam Smith: When the desire to better one's conditions does not better one's condition and society's condition ... '. Journal of the History of Economic Thought, 31 (1): 79-92.

Putnam, Robert D. (2007). E Pluribus Unim: Diversity and Community in the Twenty-First Century. Scandinavian Political Studies, 30 (2): 137-74.

Rasmussen, Dennis (2006). Does 'bettering our condition' really make us better off? Adam Smith on progress and happiness. American Political Science Review, 100 (3): 309-18.

Rodrik, Dani (2008). Thinking about governance. In D. North, D. Acemonglu, F. Fukuyama and D. Rodrik (Eds.), Governance, Growth, and Development Decisionmaking. Washington DC: The World Bank: pp. 17-25.

Rosenberg, Nathan (1968). Adam Smith, consumer tastes, and economic growth. The Journal of Political Economy, 76 (3): 361-74.

Rosenberg, Nathan (1990). Adam Smith and the stock of moral capital. History of Political Economy, 22 (1): 1-17.

Rowley, Charles (2000). Political culture and economic performance in Sub-Saharan Africa. European Journal of Political Economy, 16 (1): 133-58.

Samuels, Warren (2007). Some preliminary conclusions on the use of the concept of the invisible hand. Working paper presented at the HES conference, June 2007.

Seabright, Paul (2004). The Company of Strangers: A Natural History of Economic Life. Princeton/Oxford: Princeton University Press.

Smith, Adam (1759 [1984]). The Theory of Moral Sentiments. Indianapolis: Liberty Press.

Smith, Adam (1776 [1981]). An Inquiry into the Nature and Causes of the Wealth of Nations. Indianapolis: Liberty Press.

Tullock, Gordon (1975). The transitional gain trap. Bell Journal of Economics, 6 (2): 671-8.

Witztum, Amos (1994). Privatization, distribution and economic justice: Efficiency in transition. In Saul Estrin (Ed.), Privatization in Central and Eastern Europe. London/ New York: Longman: pp. 92-124.

Witztum, Amos (2008). Social attitudes and re-distributive policies. The Journal of SocioEconomics, 37 (4): 1597-623.

Zweynert, Joachim and Goldschmidt, Nils (2006). The two transitions in Central and Eastern Europe as processes of institutional transplantation. Journal of Economic Issues, XL (4): 895-918. 


\begin{abstract}
If Adam Smith were asked about transitioning and developing economies today, one may infer, he might suggest introducing small, yet constant, opportunities for wealth accumulation, avoiding the sudden accumulation of riches. Good institutions and the moral rules often needed to comply with them are more likely to be disregarded if there are large, sudden material gains, such as new wealth generated by the sudden opening of markets or government granting monopolies. For Smith, the desire to show off in front of others can inhibit moral behaviour and respect for good institutions, generating perverse incentives that hinder growth. Gradual change is to be preferred.
\end{abstract}

\title{
Keywords
}

Adam Smith, developing economies, transitioning economies, gradualism, vanity, approbation 